\title{
MAKNA AMBIGUITAS PESAN PEMBERDAYAAN MASYARAKAT (Studi Kasus: Kampanye Sosial "Ketimbang Ngemis" di Media Sosial)
}

\author{
${ }^{1}$ Yusmawati \\ ${ }^{2}$ Restiawan Permana \\ ${ }^{1}$ Prodi Periklanan Akademi Komunikasi BSI Jakarta \\ ${ }^{2}$ Prodi Manajemen Komunikasi Institut STIAMI \\ Email: ${ }^{1}$ yusmawati.ymw@bsi.ac.id , ${ }^{2}$ restiawan.pmn@gmail.com
}

\section{ARTICLE INFO ABSTRACT}

Keywords:

Meaning Ambiguity,

Empowerment, Social

Campaign
As a tool to create community empowerment, Community of Ketimbang Ngemis invites people to participate in social activities by providing information in the form of messages addressed through their social media accounts. Social campaign activities by Community of Ketimbang Ngemis aim to educate, invite, and awaken the community through information published on social media. However, for example, the speech meaning cannot be released from context. The same speech spoken in different situations has the potential to have different meanings. Therefore, the term of Ketimbang Ngemis raises an ambiguous meaning. If it is analyzed based on denotative meaning, this term has the impression that all elderly and disabled people are always begging. Besides that, it can be seen the use of connotative meaning, the terms contained in the wider community so as not to pity the beggars because begging behavior is lazy behavior, which makes a person become helpless and self-sufficient without any connection with others.

\section{PENDAHULUAN}

Masalah kemiskinan merupakan hal yang perlu mendapatkan perhatian khusus untuk dipikirkan guna mencari jalan keluarnya. Pembangunan yang tidak merata, kurangnya pemberdayaan masyarakat, serta pembentukan pola pikir yang salah membuat masyarakat hanya dijadikan obyek pembangunan oleh pemerintah. Kondisi ini terus menerus menjadi permasalahan klasik dalam konsep pembangunan di di Indonesia. Selain masalah-masalah tersebut, ketimpangan ekonomi, pengelolaan uang yang tidak tepat, dan pengeluaran atau belanja negara yang tidak sebanding dengan pendapatan juga dapat menyebabkan terjadinya defisit pada keuangan negara sehingga membuat kondisi perekonomian negara menurun.

Salah satu hal yang memungkinkan untuk mendukung terealisasinya program-program pembangunan adalah dengan menerima bantuan-bantuan asing. Bantuan-bantuan tersebut istilahnya beragam, seperti pinjaman, hutang, dan investasi. Namun, ketiganya memiliki konsep yang sama, yaitu adanya sistem pengembalian ke negara pemberi bantuan. Kondisi ini secara turun menurun membentuk pola ketergantungan bagi bangsa Indonesia terhadap negara lain. Sebagian masyarakat masih belum mampu menghargai dirinya sendiri atas kemampuan yang mereka miliki. Fenomena yang berhubungan dengan ketergantungan bagi masyarakat Indonesia adalah hidup pasrah dengan kondisi seadanya sehingga terbiasa menerima bantuan orang lain, dan juga menstimulus muncul perilaku mengemis. Menurut pengamatan penulis, perilaku negatif ini biasa ditemukan di kota-kota besar di Indonesia seperti Jakarta, Bandung, dan Yogyakarta. Pemerintah Kota di masing-masing kota tersebut bahkan mengeluarkan Peraturan Daerah (Perda) yang melarang masyarakat memberi sesuatu kepada para pengemis. Namun, langkah tersebut nyatanya kurang efektif. Kesadaran masyarakat yang memberi maupun yang menerima keduanya sama-sama belum mengerti dampak bilamana hal itu terus-menerus dilakukan.

Diperlukan upaya-upaya yang dapat menyadarkan seluruh elemen masyarakat untuk mengoreksi pola pikir dan tindakan-tindakan sosialnya selama ini, di mana bisa jadi, terbangun sejak masa lalu. Kemudian, sambil tidak tinggal diam berbuat sesuatu untuk memikirkan masa depan 
masyarakat, baik berbentuk tindakan di tingkat kognitif, afektif, konatif. Alasan itulah yang akhirnya menumbuhkan inisiatif bagi masyarakat (aktivis) untuk menggunakan media komunikasi guna menciptakan sebuah aksi kolektif berbasis pemberdayaan masyarakat.

Media komunikasi adalah semua sarana yang dipergunakan untuk memproduksi, mereproduksi, mendistribusikan atau menyebarkan dan menyampaikan informasi. Media komunikasi sangat berperan dalam kehidupan masyarakat. Proses pengiriman informasi di jaman keemasan ini sangat canggih. Teknologi telekomunikasi paling dicari untuk menyampaikan atau mengirimkan informasi ataupun berita karena teknologi telekomunikasi semakin berkembang, semakin cepat, tepat, akurat, mudah, murah, efektif dan efesien (Rahmawati, 2016). Ada beberapa fungsi media komunikasi yang berteknologi tinggi, yaitu: efisiensi penyebaran informasi, dengan adanya media komunikasi terlebih yang hi-tech akan lebih membuat penyebaran informasi menjadi efisien; memperkuat eksistensi informasi, dengan adanya media komunikasi yang hi-tech kita dapat membuat informasi atau pesan lebih kuat berkesan terhadap audiensi: mendidik/mengarahkan/persuasi, media komunikasi yang berteknologi tinggi dapat lebih menarik audiens; menghibur (entertain/joyfull), media komunikasi berteknologi tinggi tentunya lebih menyenangkan (bagi yang familiar) dan dapat memberikan hiburan tersendiri bagi audiens; kontrol sosial, media komunikasi yang berteknologi tinggi akan lebih mempunyai fungsi pengawasan terhadap kebijakan sosial[1].

Salah satu media komunikasi berteknologi tinggi adalah internet. Internet bukan lagi sebagai barang mahal dan asing bagi masyarakat Indonesia di era digital sekarang ini. Kemunculan teknologi internet secara otomatis turut pula memengaruhi perkembangan penggunaan media sosial di masyarakat. Media sosial adalah media online yang mendukung interaksi sosial. Media sosial menggunakan teknologi berbasis web yang mengubah komunikasi menjadi dialog interaktif. Beberapa contohnya antara lain, jejaring sosial, blog, wiki, Youtube, dan lain-lain. Melalui media sosial, setiap orang bisa membuat, menyunting sekaligus mempublikasikan sendiri konten berita, promosi, artikel, foto, dan video. Selain lebih fleksibel dan luas cakupannya, lebih efektif dan efisien, cepat, interaktif, dan variatif.

Kegiatan kolektif yang menggunakan media sosial ini dinamakan Ketimbang Ngemis. Aksi tersebut dilakukan secara masif dan terorganisir dengan maksud menyadarkan masyarakat agar tidak memberi sesuatu (materi atau uang) kepada pengemis. Melalui media sosial, pemilik akun memuat informasi berupa foto lengkap dengan caption-nya. Menurut Shirky dalam Nasrullah (2015)[2], media sosial dan perangkat lunak sosial merupakan alat untuk meningkatkan kemampuan pengguna untuk berbagi (to share), bekerja sama (to-co-operate) diantara pengguna dan melakukan tindakan secara kolektif yang semuanya berada di luar kerangka institusional maupun organisasi.

Penggunaan media sosial oleh Komunitas Ketimbang Ngemis ini ditujukan ke seluruh pengguna media sosial khususnya generasi muda yang tumbuh dan besar di era digital atau biasa disebut generasi milenial. Sebagai komunitas yang berperan dalam pemberdayaan masyarakat, Komunitas Ketimbang Ngemis mengajak masyarakat untuk ikut serta dalam memberikan informasi berupa pesan-pesan pemberdayaan melalui akun media sosialnya masing-masing. Pesan-pesan tersebut apabila dirangkai akan menghasilkan arti tertentu. Pesan yang biasa kita gunakan apabila dirangkai akan membentuk bahasa, yang merupakan sarana penting dalam suatu interaksi sosial. Dalam perannya sebagai sarana interaksi sosial, bahasa mampu menyampaikan informasi dari manusia satu ke manusia yang lain.

Sebagai alat komunikasi, bahasa terdiri atas dua bagian, yaitu bentuk atau lambang yang berupa ujaran-ujaran dan makna. Mempelajari makna kata pada hakikatnya berarti mempelajari bagaimana para pemakai bahasa dalam suatu masyarakat bahasa menafsirkan lambang-lambang bahasa untuk dapat saling mengerti. Implikasi dari tiap-tiap oposisi itu ialah bahwa pada oposisi tunggal makna bahasa. Bersifat monointerpretasi sementara pada oposisi multilateral maknanya bersifat multiinterpretasi. Yang dimaksud monointerpretasi ialah hanya terdapat satu kemungkinan interpretasi dari bahasa yang dituturkan atau dituliskan, sedangkan multiinterpretasi berarti dalam suatu tanda bahasa terdapat beragam makna atau sebaliknya sehingga apa yang ingin disampaikan penutur diinterpretasikan berbeda oleh pendengar[3].

Pemaknaan suatu tanda bahasa secara multiinterpretasi ini menimbulkan apa yang kemudian disebut ambiguitas (ambiguily). Selain itu, ketaksaan dapat ditimbulkan pula karena kearbitreran dan kekonvensionalan tanda, yang menyebabkan makna atau konsep memiliki dua sifat, yaitu samar-samar (vaque) dan taksa (ambigue). Menurut Kempson (dalam Purwanti, 2013)[4], kesamaran merupakan 
sifat bahasa berupa kecenderungan tanda Bahasa mengungkapkan makna dalam batas-batas yang tidak jelas.

Ambiguitas banyak ditemukan dalam media massa, seperti suratkabar dan televisi. Namun kini ambiguitas juga muncul di media sosial. Pesan di media sosial memiliki konvensi tersendiri sebagai suatu sistem tanda. Makna yang disampaikan tidak diutarakan sekedar melalui tuturan, tetapi juga melalui gambar atau bentuk visual dan yang memperkuat simbol atau citra yang ingin ditampilkan oleh pesan tersebut. Pesan-pesan tersebut bertujuan untuk memengaruhi dan mengajak.

Penelitian ini penting untuk dilakukan agar masyarakat tidak terjebak pada kesalahan dalam menafsirkan suatu pesan, khususnya pesan yang berkaitan dengan banyak orang. Karena multiinterpretasi juga sering terjadi apabila pesan digunakan banyak orang, yang berbeda-beda karakteristik, pengetahuan, dan pengalaman. Berdasarkan latar belakang di atas, maka rumusan masalah dalam penelitian ini adalah bagaimana makna ambiguitas pesan pemberdayaan dalam kampanye sosial "Ketimbang Ngemis" di media sosial. Sedangkan tujuan penelitian ini dilakukan adalah untuk mengetahui bagaimana makna ambiguitas pesan pemberdayaan dalam kampanye sosial "Ketimbang Ngemis" di media sosial.

\section{TINJAUAN PUSTAKA}

\subsection{Media Sosial dan Perkembangannya}

Van Dijk dalam Nasrullah (2015) menyatakan bahwa media sosial adalah platform media yang memfokuskan pada eksistensi pengguna yang memfasilitasi mereka dalam beraktifitas maupun berkolaborasi. Karena itu, media sosial dapat dilihat sebagai medium (fasilitator) online yang menguatkan hubungan antar pengguna sekaligus sebuah ikatan sosial. Sedangkan Meike dan Young dalam Nasrullah (2015), mengartikan kata media sosial sebagai konvergensi antara komunikasi personal dalam arti saling berbagi diantara individu (to be share one-to-one) dan media publik untuk berbagi kepada siapa saja tanpa ada kekhususan individu. Berdasarkan definisi-definisi tersebut, penulis memahami bahwa media sosial merupakan media yang digunakan untuk menghubungkan satu orang ke banyak orang atau banyak orang (komunitas) ke komunitas lainnya dengan saling berbagi informasi satu sama lain.

Karakteristik media sosial tidak jauh berbeda dengan media siber (cyber) dikarenakan media sosial merupakan salah satu platform dari media siber. Namun demikian, media sosial memiliki karakter khusus, yaitu: 1. Jaringan (Network). Jaringan adalah infrastruktur yang menghubungkan antara komputer dengan perangkat keras lainnya. Koneksi ini diperlukan karena komunikasi bisa terjadi jika antar komputer terhubung, termasuk di dalamnya perpindahan data. 2. Informasi (Informations). Informasi menjadi entitas penting di media sosial karena pengguna media sosial mengkreasikan representasi identitasnya, memproduksi konten, dan melakukan interaksi berdasarkan informasi. 3. Arsip (Archive). Bagi pengguna media sosial, arsip menjadi sebuah karakter yang menjelaskan bahwa informasi telah tersimpan dan bias diakses kapanpun dan melalui perangkat apapun. 4. Interaksi (Interactivity). Media sosial membentuk jaringan antar pengguna yang tidak sekedar memperluas hubungan pertemanan atau pengikut (follower) semata, tetapi harus dibangun dengan interaksi antar pengguna tersebut. 5. Simulasi Sosial (Simulation of Society). Media sosial memiliki karakter sebagai medium berlangsungnya masyarakat (society) di dunia virtual. Media sosial memiliki keunikan dan pola yang dalam banyak kasus berbeda dan tidak dijumpai dalam tatanan masyarakat yang real. 6. Konten oleh pengguna (User-Generated Content). Di Media sosial, konten sepenuhnya milik dan berdasarkan kontribusi pengguna atau pemilik akun. UGC merupakan relasi simbiosis dalam budaya media baru yang memberikan kesempatan dan keleluasaan pengguna untuk berpartisipasi. Hal ini berbeda dengan media lama (tradisional) dimana khalayaknya sebatas menjadi objek atau sasaran yang pasif dalam distribusi pesan (Nasrullah, 2015).

\subsection{Pemberdayaan Masyarakat Berbasis Partisipatif}

Dalam penelitiannya yang berjudul Model Pemberdayaan Masyarakat di Desa Sumber Rahayu Kecamatan Limbangan Kendal Jawa Tengah menyebutkan bahwa peran kemampuan pelaku pemberdayaan akan efektif dapat meningkatkan keberdayaan masyarakat jika masyarakat sebelumnya meningkatkan pemberdayaannya. Pelaku pemberdayaan tidak dapat langsung berpengaruh terhadap keberdayaan masyarakat, tetapi harus dimediasi dengan proses yang mengiringi pemberdayaan. 
Peningkatan pemberdayaan sebagai penentu keberhasilan pelaku dalam upaya peningkatan keberdayaan masyarakat (Widjajanti, 2011)[5].

Sasaran utama pemberdayaan masyarakat adalah mereka yang lemah dan tidak memiliki daya, kekuatan atau kemampuan mengakses sumberdaya produktif atau masyarakat yang terpinggirkan dalam pembangunan. Tujuan akhir dari proses pemberdayaan masyarakat adalah untuk memandirikan warga masyarakat agar dapat meningkatkan taraf hidup keluarga dan mengoptimalkan sumberdaya yang dimilikinya. Keberdayaan masyarakat dapat diwujudkan melalui partisipasi aktif masyarakat yang difasilitasi dengan adanya pelaku pemberdayaan.

Partisipasi dan pemberdayaan merupakan hal yang menjadi pusat perhatian dalam proses pembangunan belakangan ini di berbagai negara. Kemiskinan yang terus melanda dan menggerus kehidupan masyarakat akibat resesi internasional yang terus bergulir dan proses restrukturisasi menunjukkan perhatian yang sangat besar terhadap strategi partisipasi sebagai sarana percepatan proses pembangunan. Partisipasi dan pemberdayaan merupakan strategi yang sangat potensial dalam rangka meningkatkan ekonomi, sosial dan transformasi budaya. Proses ini pada akhirnya akan dapat menciptakan pembangunan yang lebih berpusat pada rakyat (people centered) (Muslim, 2007)[6].

\subsection{Pemanfaatan Media Sosial dalam Pemberdayaan Masyarakat}

Dalam pemberdayaan masyarakat diperlukan partisipasi publik agar tujuan pemberdayaan dapat tercapai. Oleh sebab itu, harus dilakukan juga upaya sosialisasi agar publik dapat mengetahuinya. Salah satu upaya yang dapat dilakukan untuk kembali untuk meningkatkan partisipasi publik khususnya generasi muda adalah dengan melaksanakan edukasi tentang pentingnya pemberdayaan masyarakat sebagai media penyampaian konsep pemberdayaan masyarakat yang memiliki tujuan akhir untuk membuat warga negara menjadi lebih sadar. Warga negara yang sadar akan pemberdayaan masyarakat adalah warga negara yang sadar akan hak dan kewajiban sehingga dapat ikut serta dalam kehidupan berbangsa dan bernegara dalam setiap proses pembangunan.

Edukasi tentang pemberdayaan masyarakat saat ini berkembang cukup pesat di media sosial. Tidak perlu disebutkan lagi pengaruh media sosial terhadap seorang individu. Terlebih dengan kehadiran media baru ini terus mengalami perkembangan. Media sosial muncul didasari ide untuk menghubungkan orang-orang dari seluruh belahan dunia. Kini media sosial digunakan untuk mendukung berbagai aktivitas. Baik individu maupun organisasi. Kebanyakan dari pengguna media sosial adalah generasi muda. Hampir semua generasi muda kini familiar dengan jejaring sosial seperti Twitter dan Instagram.

Hal tersebut di atas seperti penelitian yang penulis lakukan sebelumnya tentang bagaimana Pos Keadilan Peduli Ummat (PKPU) sebagai organisasi sosial menggunakan media sosial Twitter untuk mendukung segala bentuk aktivitas sosialnya. Melalui media sosial menghasilkan penyebaran pesan yang berlangsung cepat dan masif. Jadi tidak heran kalau media sosial menjadi target bagi para organisatoris untuk melakukan "gerakan" (Permana, 2014)[7].

Selain penelitian di atas, pemanfaatan Twitter sebagai media edukasi juga pernah dilakukan oleh Sari (2014)[8], menunjukkan bahwa melalui Twitter masyarakat akan semakin mudah untuk belajar mengenai dunia politik sehingga bisa lebih kritis kepada kebijakan-kebijakan yang pemerintah ambil tanpa terkesan asal dan mengada-ada. Intinya, lewat jejaring sosial pemerintah akan mampu mengedukasi masyarakat untuk berani berperan aktif dalam politik Indonesia.

Sedangkan salah satu penelitian penggunaan media sosial Instagram dilakukan oleh Retnasary dan Fitriawati (2018)[9]. Hasilnya menunjukkan bahwa aktivitas Ketimbang Ngemis memanfaatkan Instagram sebagai media promosi untuk menggalang dana bagi orang-orang yang membutuhkan, respon followers sangat dipengaruhi oleh tren, selera, dan media habit.

\subsection{Makna Ambiguitas Pada Pesan di Media Massa}

Ambiguitas dalam bahasa tulis hanya ada dua jenis, yaitu ambiguitas gramatikal, dan ambiguitas leksikal. Perbedaan ambiguitas gramatikal dan ambiguitas leksikal, yaitu pada ambiguitas gramatikal muncul pada satuan kebahasaan yang disebut kalimat atau kelompok kata, sedangkan pada ambiguitas leksikal setiap kata dapat memiliki makna lebih dari satu karena mengacu pada benda yang berbeda disesuaikan dengan lingkungan pemakainya (Anwari et al., 2011)[10].

Sedangkan Purwanti (2013) melalui penelitiannya yang berjudul Makna Ambiguitas Slogan Iklan Sepeda Motor di Televisi, menunjukkan bahwa sebagai suatu peristiwa tutur pemaknaan 
terhadap tuturan tidak dapat begitu saja dilepaskan dari konteks. Tuturan yang sama yang diucapkan pada situasi yang berbeda berpotensi untuk memiliki makna yang berbeda pula. Komunikasi bahasa yang terjadi melalui proses penafsiran dianggap berhasil jika lawan tutur dapat memahami pesan secara persis sama dengan apa yang disampaikan penutur. Sebaliknya, komunikasi itu dianggap tidak berhasil jika lawan tutur menafsirkan tuturan secara berbeda dari apa yang dimaksud oleh penuturnya[4].

Beberapa penyebab ambiguitas, yaitu kurangnya penanda ejaan, kesalahan letak suatu unsur dalam kalimat, pemilihan kata yang kurang sepadan dengan teks bahasa sumber, serta adanya homonim dan polisemi. Pada bahasa sumber pun ambiguitas dapat muncul karena adanya homonim dan polisemi. Ambiguitas berasal dari bahasa Inggris yaitu ambiguity yang berarti suatu konstruksi yang dapat ditafsirkan lebih dari satu arti. Keambiguan yang mengakibatkan terjadinya lebih dari satu makna ini dapat terjadi saat pembicaraan lisan ataupun dalam keadaan tertulis. Agar pembahasan menjadi terfokus, dalam penelitian ini pengamatan ditujukan pada pesan kampanye sosial Ketimbang Ngemis di media sosial Twitter dan Instagram.

\subsection{Semiotika Teks}

Semiotika teks adalah cabang semiotika yang secara khusus mengkaji teks dalam berbagai bentuk dan tingkatannya. Ia dibedakan dengan semiotika umum (general semiotics), yang mengkaji tanda secara lebih umum dan lebih luas. Disebut sebagai semiotika teks oleh karena unit analisisnya adalah teks itu sendiri, sementara unit analisis terkecil semiotika umum adalah tanda.

Analisis teks (textual analysis) adalah salah satu cabang dari semiotika teks, yang secara khusus mengkaji teks sebagai sebuah 'produk penggunaan bahasa' berupa kumpulan atau kombinasi tanda-tanda, khususnya yang menyangkut sistem tanda (sintatik/paradigmatic), tingkatan tanda (denotasi/konotasi), relasi antartanda (metafora/metonim), muatan mitos, dan ideologi di baliknya.

Semiotika yang digunakan dalam penelitian ini adalah semiotik Roland Barthes. Barthes menjelaskan dua tingkat dalam pertandaan, yaitu denotasi dan konotasi. Denotasi adalah tingkat pertandaan yang menjelaskan hubungan antara penanda dan petanda, atau antara tanda dan rujukannya pada realitas, yang menghasilkan makna yang eksplisit, langsung, dan pasti. Denotasi adalah tingkatan pertandaan yang paling konvensional di dalam masyarakat, yaitu elemen-elemen tanda yang maknanya cenderung disepakati secara sosial. Seadangkan konotasi adalah tingkat pertandaan yang menjelaskan hubungan antara penanda dan petanda, yang didalamnya beroperasi makna yang tidak eksplisit, tidak langsung dan tidak pasti (artinya terbuka terhadap berbagai kemungkinan tafsiran). Ia menciptakan makna-makna lapis kedua, yang terbentuk ketika penanda dikaitkan dengan berbagai aspek psikologis, seperti perasaan, emosi atau keyakinan, yang disebut makna konotatif (Piliang, 2004)[11].

\section{METODE PENELITIAN}

Pendekatan penelitian yang digunakan dalam penelitian ini adalah pendekatan kualitatif. Sebagai salah satu pendekatan yang menjelaskan tentang fenomena atau disebut juga studi kasus termasuk kedalam jenis metode empiris. Subjek penelitian adalah akun Instagram Ketimbang Ngemis. Jenis data yang digunakan berupa data primer dan data sekunder. Data primer diperoleh studi dokumentasi yang dilakukan peneliti pada unggahan akun Instagram Ketimbang Ngemis, diantaranya unggahan foto dan caption dalam akun media sosial tersebut. Sementara itu, data sekunder diperoleh dari laporan-laporan yang relevan dengan penelitian ini.

Jenis penelitian yang digunakan dalam penelitian ini yaitu bersifat interpretatif. Interpretif melihat fakta sebagai sesuatu yang unik dan memiliki konteks dan makna yang khusus sebagai esensi dalam memahami makna sosial. Interpretif melihat fakta sebagai hal yang cair (tidak kaku) yang melekat pada sistem makna dalam pendekatan interpretatif. Fakta-fakta tidaklah imparsial, objektif dan netral. Fakta merupakan tindakan yang spesifik dan kontekstual yang beragantung pada pemaknaan sebagian orang dalam situasi sosial. Interpretif menyatakan situasi sosial mengandung ambiguisitas yang besar. Perilaku dan pernyataan dapat memiliki makna yang banyak dan dapat dinterpretasikan dengan berbagai cara (Newman, 1997)[12].

\section{HASIL DAN PEMBAHASAN}

\subsection{Komunitas Ketimbang Ngemis dan Kampanye di Media Sosial}

Yusmawati et al. (Makna Ambiguitas Pesan Pemberdayaan Masyarakat...) 
Komunitas yang diprakarsai oleh anak muda bernama Rizky dari Yogyakarta ini, mengusung tagline "Say NO to 'MENGEMIS': Belilah Walau Tidak Butuh Sekalipun". Pada awalnya, ia sekedar memposting di akun media sosial pribadinya karena haru melihat perjuangan dari seorang nenek dan kakek dalam menjalani hidup. Kemudian ia tak menyangka dari postingannya tersebut banyak yang antusias dan memberikan respon positif. Hingga akhirnya Rizky membuat akun Instagram @ketimbang.ngemis agar makin banyak orang yang sadar untuk membantu para manula dan penyandang cacat di kota masing-masing. Menurut Boyd dan Nasrullah (2015), media sosial merupakan kumpulan perangkat lunak yang memungkinkan individu maupun komunitas untuk berkumpul, berbagi, berkomunikasi, dan dalam kasus tertentu saling berkolaborasi atau bermain. Media sosial memiliki kekuatan pada User Generated Content (UGC) dimana konten dihasilkan oleh pengguna, bukan oleh editor sebagaimana di institusi media massa.

Berkat media sosial, akun ini menyebar begitu cepat, akhirnya menarik para anak muda dari kota yang berbeda untuk menggerakan akun ini menjadi sebuah perkumpulan alias komunitas. Komunitas ini dibentuk untuk mengapresiasi dan membantu para sosok mulia, yakni orang tua yang masih mau berusaha dalam keterbatasan fisik maupun usia untuk mencari nafkah bagi diri sendiri dan keluarganya serta menolak untuk mengemis. Aktivitas yang dijalankan Komunitas Ketimbang Ngemis salah satunya adalah dengan memberikan informasi dan berita mengenai sosok mulia tersebut ke masyarakat luas melalui media sosial Ketimbang Ngemis. Selain itu, ada juga kegiatan bakti sosial dengan menyalurkan donasi ke sosok mulia di setiap bulannya. Seperti yang dilakukan @ ketimbang.ngemis.jakarta. Ketimbang Ngemis Jakarta alias KNJ yang berdiri pada 18 Juni 2015 ini merupakan inisiatif dari seorang gadis bernama Yona Luverin bersama lima kawannya. Yona juga terpilih menjadi admin sekaligus Ketua Umum KNJ. Walaupun di usianya yang bisa dibilang muda yaitu 20 tahun, tak menyurutkan langkahnya ingin berkontribusi dalam membantu sesama.

Sebagai implementasinya, saat ini komunitas serupa juga terus bertambah jumlahnya dalam melakukan kegiatan-kegiatan kampanye sosial untuk mengajak seluruh masyarakat agar concern terhadap isu-isu terkini. Kampanye perubahan sosial merupakan suatu usaha terpadu yang diarahkan oleh satu kelompok yang bertujuan memengaruhi orang lain untuk menerima, mengubah atau melepaskan ide-ide, kebiasaan atau perilaku tertentu. Usaha terpadu ini dilakukan oleh komunitas Ketimbang Ngemis melalui kegiatan kampanyenya dengan mengangkat isu-isu sosial yang bertujuan untuk membangun kesadaran masyarakat terhadap perilaku mengemis yang dianggap sebagai perilaku negatif karena dinilai malas, tidak mau bekerja, sehingga menimbulkan ketidakmandirian dikarenakan hidupnya selalu bergantung dengan orang lain. Sejak beberapa tahun lalu, komunitas ini aktif mengampanyekan pesan-pesan di media sosial, seperti pada akun @ketimbangngemis di Twitter dan @ ketimbang.ngemis di Instagram.

Komunitas ini berharap aksinya dilihat, didukung dan dibantu, dengan begitu mereka bisa membantu mengurangi angka kemiskinan di Indonesia. Potret pengemis khususnya di kota-kota besar, bisa kita temukan di jembatan penyeberangan, lampu merah, bahkan di bus kota. Kini pemandangan itu menjadi hal yang tidak asing lagi. Tetapi ironisnya yang mengemis itu masih muda, seharusnya masih kuat untuk bekerja. Sedangkan orang yang sudah tua (lansia) masih memiliki semangat untuk bekerja, misalnya dengan berjualan. Sudah sepantasnya mereka ini mendapat perhatian dari banyak orang. Namun mereka tidak memelas. Tidak juga mengemis untuk belas kasih. Mereka pilih berusaha berjualan ketimbang menadah bantuan saja.

Hal ini memunculkan inisiatif bagi para followers Twitter dan Instagram Komunitas Ketimbang Ngemis untuk mengajak atau menyadarkan masyarakat melalui informasi-informasi yang mereka muat di media sosial. Isinya tentang orang-orang yang menolak mengemis dan memilih berjualan. Akun ini juga mengkampanyekan 'membeli jualan meski tidak sedang kita butuhkan'. Adapun informasi-informasi tersebut di antaranya:

"Kedua orang lanjut usia ini lebih memilih berjualan komoditi apa adanya daripada harus ngemis. Foto ini diambil di Kota Bogor".

"Kalau ke Pasar Krian, Sidoarjo, kamu akan menemukan nenek ini berjualan sayur ala kadarnya dari pukul 10 pagi sampai 9 malam demi sesuap nasi".

"Kali ini di kota Palembang, ada seorang nenek yang berjualan kacang demi menyambung hidupnya".

"Pasar Bendungan, Semarang, jadi tempat nenek ini menawarkan jasa membawakan barang belanjaan sampai ke parkiran bus". 
"Kalau di Bandung, ada nenek Sumiyem yang berjualan sate di Jalan Sultan Agung".

"Nenek ini menjajakan makanan-makanan kecil di Pasar Baluran, Surabaya".

"Di Jalan Kauman, Yogya kamu akan menemukan seorang nenek penjual wedang ronde."

"Sesulit-sulitnya hidup, orang-orang di atas tak pernah memilih jalan mudah. Kamu jangan sampai mau kalah ya!”.

Kegiatan Komunitas Ketimbang Ngemis didasarkan kepada aksi sosial yang ditujukan agar para anggota lebih peduli dan memiliki rasa sosial yang tinggi antar sesamanya. Selain mendorong untuk membeli barang dagangan mereka, akun ini juga aktif mengumpulkan donasi. Bisa berupa uang maupun bahan sembako. Jika sudah terkumpul, donasi akan langsung diberikan kepada para pejuang ini. Kini jumlah followers-nya berjumlah 110.000 .

\subsection{Ambiguitas Istilah KETIMBANG NGEMIS}

Ketika kita menyampaikan suatu pesan kepada seseorang baik secara lisan maupun secara tertulis, orang tersebut diharapkan dapat menangkap apa yang kita maksud. Namun, ada kalanya dalam berkomunikasi terjadi ketidaksesuaian makna atau disebut salah paham. Kesalahpahaman tersebut antara lain karena makna yang ingin disampaikan oleh penulis dan pembaca tidak dipahami secara sama oleh mereka. Dalam hal ini, penulis menemukan adanya ambiguitas pada istilah Ketimbang Ngemis di media sosial. Istilah ini mengandung dua pengertian yang berbeda. Apabila dianalisis berdasarkan semiotik teks milik Roland Barthes, maka makna denotatif istilah Ketimbang Ngemis berarti mengemis merupakan pekerjaan yang tidak bernilai dan lebih baik melakukan pekerjaan yang lebih layak.

"Basri, kakek berusia 75 tahun ini lebih memilih berjualan sapu lidi daripada harus ngemis. Biasanya, beliau berjualan di Fakultas Kedokteran Universitas Baiturramah, Padang".

"Tengok juga kisah Pak Salim yang tunanetra. Dengan segala keterbatasan, Salim tetap berjualan krupuk di sekitaran tebet. Akun ini rutin mendorong agar kita jika bertemu mereka, jangan ragu untuk membeli dagangannya!".

Penulis menilai secara subyektif, dalam pesan-pesan di atas telah terjadi konstruksi pemikiran yang "menggunakan" label lansia baik secara konsep maupun visual sebagai subyek kampanye Ketimbang Ngemis. Telah terjadi pula konstruksi citra yang menyatakan bahwa umumnya lansia dan tunanetra menjalankan aktivitas mengemis. Kesalahan pada komunitasnya memang tidak, namun memunculkan pemaknaan berbeda dari kata "Ngemis"-nya sehingga memunculkan penafsiran bahwa komunitas ini memandang sempit bahwa seorang lansia tidak dapat menjalankan aktivitas lain seperti berjualan, bertani, atau berkebun. Nyatanya, banyak penderita tunanetra memiliki keterampilan khusus seperti menyanyi atau memijat yang dapat menghasilkan uang guna memenuhi kebutuhan hidupnya. Selain itu, pesan ini dapat membentuk citra tersendiri bagi kedua golongan masyarakat tadi sebagai pihak yang tidak berdaya atau lemah.

Sedangkan makna konotatif dari istilah Ketimbang Ngemis berarti upaya menyadarkan masyarakat luas bahwa perilaku mengemis adalah perilaku malas, yang membuat seseorang menjadi tidak berdaya dan mampu hidup mandiri tanpa adanya ketergantungan dengan pihak lain. Karena para pengemis menganggap mengemis adalah pekerjaan mudah yang sangat mudah, sehingga menjadi alasan bagi seseorang yang tidak mau berusaha untuk mencari cara lain. Ngemis merupakan pekerjaan/kegiatan yang memiliki derajat paling rendahdan tidak memiliki harga diri. Kondisi ini yang menyebabkan ketergantungan dengan orang yang lebih kuat/mampu, baik secara sosial dan ekonomi. Ngemis dilabelkan pada aktivitas orang-orang yang tidak berdaya, miskin, dan malas. Apabila perilaku ini tidak dicegah atau dibiarkan, maka jumlah pengemis akan bertambah karena mereka mengganggap bahwa pekerjaan itu mudah dilakukan cukup hanya dengan dengan keterampilan seadanya, seperti dengan memelas mengharapkan bantuan orang lain.

\section{SIMPULAN DAN SARAN}

Berdasarkan pembahasan di atas dapat disimpulkan bahwa kegiatan kampanye sosial oleh Komunitas Ketimbang Ngemis bertujuan untuk mengedukasi, mengajak, dan menyadarkan masyarakat melalui informasi-informasi yang dimuat di media sosial. Namun, sebagai suatu peristiwa 
tutur, pemaknaan terhadap tuturan tidak dapat begitu saja dilepaskan dari konteks. Tuturan yang sama yang diucapkan pada situasi yang berbeda berpotensi untuk memiliki makna yang berbeda pula. Oleh sebab itu, istilah Ketimbang Ngemis memunculkan makna yang ambigu. Apabila dianalisis berdasarkan makna denotatif, istilah ini memiliki kesan bahwa sebagian besar lansia dan penderita cacat akan melakukan tindakan mengemis. Sedangkan dilihat berdasarkan makna konotatif, istilah ini berisi ajakan kepada masyarakat luas agar tidak mengasihani para pengemis karena perilaku mengemis adalah perilaku malas, yang membuat seseorang menjadi tidak berdaya dan mampu hidup mandiri tanpa adanya ketergantungan dengan pihak lain.

Isu tentang perilaku mengemis sebenarnya bukan suatu hal yang baru. Isu ini barangkali sudah menghiasi berbagai wacana sehingga pernah diangkat kedalam undang-undang berupa Peraturan Daerah di beberapa wilayah di Indonesia. Namun, undang-undang tersebut dinilai kurang efektif karena tidak adanya ketegasan dalam menjalankan peraturan tersebut. Oleh sebab itu, aparat pemerintah seharusnya berperan aktif dalam penegakan hukum secara tegas dan konsisten dengan melakukan pengawasan, pendampingan, dan edukasi kepada para pengemis maupun yang bukan pengemis. Hasil penelitian ini juga menjadi bahan masukkan untuk komunitas Ketimbang Ngemis dan sejenisnya, agar tidak menyudutkan para lansia dan penyandang disabilitas dengan istilah "ngemis" karena secara tidak langsung dapat mengaitkan keduanya memiliki hubungan yang erat.

\section{DAFTAR PUSTAKA}

[1] B. Huffner, (2002). Human Communication. London: Sage Publication.

[2] R. Nasrullah, (2015), Media Sosial; Persfektif Komunikasi, Budaya, dan Sosioteknologi. Bandung: Simbiosa Rekatama Media.

[3] C. Abdul, (1995), Pengantar Semantik Bahasa Indonesia, Kedua. Jakarta: Rineka Cipta.

[4] D. Purwanti, (2013), "MAKNA AMBIGUITAS SLOGAN IKLAN SEPEDA MOTOR DI TELEVISI," Muhammadiyah Surakarta

[5] K. Widjajanti, (2011), "Model Pemberdayaan Masyarakat", J. Ekon. Pembang., vol. 12, no. 1, pp. 15-27.

[6] A. Muslim, (2007), "Pendekatan Partisipatif Dalam Pemberdayaan Masyarakat," Apl. IlmuIlmu Agama, vol. VIII, no. 2, pp. 89-103.

[7] R. Permana, (2014), “Peran Media Sosial Tiwitter@PKPU dalam Menciptakan Partisipasi Masyarakat (Kasus Pada Program Sebar Qurban Indonesia oleh Pos Keadilan Peduli Ummat)," in Media, Budaya, dan Masyarakat Urban Indonesia, pp. 219-228.

[8] Eka Rahma Sari, (2014) "Edukasi Politik Bagi Generasi Muda Indonesia Melalui Twitter," in Media, Budaya, dan Masyarakat Urban Indonesia, pp. 173-182.

[9] M. dan D. F. Retnasary, (2018), "PERAN INSTAGRAM SEBAGAI MEDIA PROMOSI," Syntax Lit., vol. 3, no. 4, p. 300

[10] Y. Anwari et al., (2013), "Analisis Kalimat Ambigu Dalam Novel," Artik. Ilm. Mhs. Univ. Bung Hatta, vol. 2, no. 3, pp. 1-8

[11] Y. A. Piliang, (2004) "Semiotika Teks : Sebuah Pendekatan Analisis Teks," Mediator, vol. 5, no. 2, pp. 189-198

[12] W. L. Newman, (2013), Social Research Methods Qualitative and Quantitative Approache. Boston: Allyn \& Bacon. 